\title{
Perbandingan Kebijakan Pelaksanaan Imunisasi Rutin pada Anak sebelum dan selama Pandemi
}

\author{
Juliarizky Shinta Dewi ${ }^{1}$, Inge Dhamanti ${ }^{2}$ \\ ${ }^{1}$ Fakultas Kesehatan Masyarakat, Universitas Airlangga, Surabaya, Indonesia \\ ${ }^{2}$ Pusat Riset Keselamatan Pasien, Universitas Airlangga, Surabaya, Indonesia \\ E-mail: juliarizky.inta.dewi-2018@fkm.unair.ac.id, inge-d@fkm.unair.ac.id
}

\begin{tabular}{l}
\hline Article Info \\
Article History \\
Received: $2022-02-03$ \\
Revised: $2022-02-22$ \\
Published: $2022-03-01$
\end{tabular}

Published: 2022-03-01

Keywords:

Policy;

Routine Immunizations;

Pandemic;

COVID-19

\begin{abstract}
Routine immunization is one of the public health efforts carried out on a scheduled basis to increase immunity and prevent immunization preventable diseases (PD3I) in children. Unfortunately, during the COVID-19 pandemic, the coverage of routine immunizations for children decreased due to concerns of parents taking their children to health services. This study was conducted to determine routine immunization service policies changes before and during the COVID-19 pandemic. This study uses a literature review. The study was conducted by comparing routine immunization service policies before and during the COVID-19 pandemic. The secondary data used in this study are the Regulation of the Minister of Health, the Decree of the Minister of Health, and technical instructions for the implementation of immunization during the COVID-1-9 pandemic. From the results of the study, it is known that there are changes in the policy of implementing immunization before and during the COVID-19 pandemic. Differences in policies are found in room provisions, service time, duties and roles of immunization officers, special services, and communication strategies. In addition, from the research, it is known that immunization policies during the COVID19 pandemic are more detailed and emphasize health protocols. The conclusion obtained is that the government has provided guidelines for the implementation of immunization during the pandemic so that parents do not have to worry about taking their children to health services so that immunization coverage can be fulfilled again.
\end{abstract}

\begin{tabular}{l}
\hline Artikel Info \\
\hline Sejarah Artikel \\
Diterima: 2022-02-03 \\
Direvisi: 2022-02-22 \\
Dipublikasi: 2022-03-01
\end{tabular}

Kata kunci: Kebijakan; Imunisasi Rutin; Pandemi; COVID-19. \begin{abstract}
Abstrak
Imunisasi rutin merupakan salah satu upaya kesehatan masyarakat yang dilakukan secara terjadwal untuk meningkatkan kekebalan tubuh dan mencegah penyakit yang dapat dicegah dengan imunisasi (PD3I) pada anak. Sayangnya selama masa pandemi COVID-19 cakupan imunisasi rutin pada anak menurun karena kekhawatiran orang tua membawa anaknya ke pelayanan kesehatan. Studi ini dilakukan untuk mengetahui perubahan kebijakan pelayanan imunisasi rutin sebelum dan selama pandemi COVID19. Penelitian ini menggunakan metode studi kepustakaan atau literature review. Penelitian dilakukan dengan membandingkan kebijakan pelayanan imunisasi rutin sebelum dan selama pandemi COVID-19. Data sekunder yang digunakan dalam penelitian ini adalah Peraturan Menteri Kesehatan, Keputusan Menteri Kesehatan, dan petunjuk teknis pelaksanaan imunisasi selama pandemi COVID-1-9. Dari hasil penelitian diketahui bahwa terdapat perubahan dalam kebijakan pelaksanaan imunisasi sebelum dan selama pandemi COVID-19. Perbedaan kebijakan terdapat pada ketentuan ruangan, waktu pelayanan, tugas dan peran petugas imunisasi, pelayanan khusus, serta strategi komunikasi. Selain itu, dari penelitian diketahui bahwa kebijakan imunisasi selama pandemi COVID-19 lebih rinci dan menekankan protokol kesehatan. Kesimpulan yang diperoleh adalah pemerintah telah memberikan pedoman untuk pelaksanaan imunisasi selama pandemi sehingga orang tua tidak perlu khawatir untuk mengantar anak ke pelayanan kesehatan agar cakupan imunisasi dapat kembali terpenuhi.
\end{abstract}

\section{PENDAHULUAN}

Imunisasi merupakan upaya kesehatan masyarakat yang diselenggarakan untuk meningkatkan kekebalan tubuh secara aktif terhadap suatu penyakit sekaligus mencegah penyakit yang dapat dicegah dengan imunisasi (PD3I) pada anak (Irawati, 2020). Penyakit yang dapat dicegah dengan imunisasi antara lain, Tuberculosis, HPV, Campak, Polio, Tetanus, Hepatitis-A, Hepatitis-B, Difteri, Pneumonia, serta Pertussis (Yundri et al., 2017). Imunisasi berdasarkan jenis penyelenggaraannya di Indonesia terbagi menjadi imunisasi wajib dan imunisasi pilihan (Kementrian Kesehatan Republik 
Indonesia, 2015). Imunisasi wajib terbagi menjadi imunisasi rutin, imunisasi tambahan, dan imunisasi khusus (Kementrian Kesehatan Republik Indonesia, 2015). Artikel ini akan berfokus pada imunisasi rutin yaitu imunisasi yang dilaksanakan secara terus menerus dan terjadwal. Imunisasi rutin terdiri dari imunisasi dasar untuk bayi dan batita, serta imunisasi lanjutan untuk anak usia sekolah dasar. Jenis vaksin yang diberikan ketika imunisasi dasar antara lain vaksin BCG, DPT-HB-HIB, Hepatitis-B, Polio oral, Inactive Polio, dan vaksin Campak (Yundri et al., 2017). Sedangkan jenis vaksin yang diberikan saat imunisasi lanjutan adalah vaksin DT, TD, dan vaksin TT (Kementrian Kesehatan Republik Indonesia, 2015). Imunisasi rutin memiliki manfaat yang sangat penting bagi anak yaitu dapat mencegah penderitaan akibat penyakit dan mencegah kematian pada anak akibat PD3I (Nurhasanah, 2021).

Imunisasi rutin juga dapat meminimalisir kemungkinan cacat pada anak akibat suatu penyakit, pemberian imunisasi juga berpengaruh terhadap tumbuh kembang anak sehingga pemberian imunisasi sangat dianjurkan oleh pemerintah, selain pada anak manfaat imunisasi dapat dirasakan oleh orang tua yaitu imunisasi dapat menjamin kesehatan anak sehingga mencegah pengeluaran biaya untuk pengobatan. Cakupan imunisasi rutin di Indonesia pada anak usia di bawah dua tahun sebelum pandemi COVID-19 menunjukkan angka yang semakin baik di tiap tahunnya (Pambudi et al., 2021). Namun berdasarkan data Kementerian Kesehatan RI, capaian imunisasi pada tahun 2020 jauh lebih rendah dibandingkan tahun 2018 dan 2019 (Putri, Saharuddin and Fitriani, 2021). Terjadinya pandemi COVID-19 berdampak pada pelaksanaan imunisasi di beberapa daerah salah satu penyebabnya adalah karena kekhawatiran orang tua membawa anaknya ke pelayanan kesehatan (Nadhifa et al., 2020). Selain kekhawatiran orang tua, terhambatnya pelaksanaan imunisasi selama masa pandemi COVID-19 diakibatkan karena kesibukan tenaga kesehatan dalam pelayanan COVID-19 serta kebijakan yang berlaku selama pandemi seperti lockdown yang menghambat pendistribusian vaksin (Mukhi and Medise, 2021). Dari data surveilans Kementerian Kesehatan RI diketahui bahwa cakupan imunisasi campak pada tahun 2020 hanya mencapai angka 45\%, sedangkan cakupan imunisasi diphtheria tetanus (DT) dan tetanus diphtheria (TD) hanya mencapai angka 40\% (Kementrian Kesehatan Republik Indonesia,
2021). Selain itu, dari 401 kabupaten/ kota hanya 200 yang cakupan imunisasinya lebih dari 80\% (Kementrian Kesehatan Republik Indonesia, 2021). Berdasarkan Laporan Kinerja Kementerian Kesehatan tahun 2020, kabupaten/kota yang mencapai $80 \%$ imunisasi dasar lengkap hanya terealisasi sebesar 46,9\% dari target 79,3\% (Kementrian Kesehatan Republik Indonesia, 2020), cakupan imunisasi yang rendah dan tidak merata dapat menyebabkan timbulnya akumulasi populasi rentan terhadap PD3I, oleh karena itu, Kementerian Kesehatan mengupayakan untuk meningkatkan cakupan imunisasi di masa pandemi saat ini.

Dampak jika anak tidak menerima imunisasi rutin adalah anak akan mudah terkena penyakit berat seperti TBC dan hepatitis, hal tersebut dapat menurunkan kualitas hidup anak karena penyakit tersebut berisiko menyebabkan disabilitas tetap. Apabila anak telah mengalami sakit maka tidak menutup kemungkinan anggota keluarga yang lain akan ikut tertular, dan yang paling membahayakan adalah dapat memunculkan wabah penyakit di lingkungan daerah tempat tinggal anak. Selain itu, jika anak telah menderita penyakit serius akibat tidak mengikuti imunisasi, maka akan dibutuhkan biaya pengobatan yang tidak mudah untuk menyembuhkan penyakit yang diderita. Sehingga dapat disimpulkan bahwa dengan pemberian imunisasi rutin secara penuh dapat mencegah penularan penyakit salah satunya COVID-19 karena imunitas tubuh bayi yang baik (Abbas et al., 2020), pelaksanaan imunisasi menjadi langkah preventif yang sangat perlu untuk diikuti sesuai dengan peraturan pemerintah. Artikel ini dibuat bertujuan mengetahui kebijakan imunisasi rutin pada anak yang dibuat untuk meningkatkan cakupan imunisasi di masa pandemi, secara spesifik artikel ini akan mencari perbedaan kebijakan pelaksanaan imunisasi rutin sebelum dan selama pandemi COVID-19 agar khalayak mengetahui perubahan kebijakan imunisasi di masa pandemi, dengan begitu para orang tua tidak perlu khawatir untuk mengimunisasikan anaknya ke pelayanan kesehatan terdekat.

\section{METODE PENELITIAN}

Penelitian ini merupakan jenis penelitian dengan menggunakan metode studi kepustakaan atau literature review dengan jenis narrative review. Penulis akan membandingkan dua kebijakan pelaksanaan imunisasi rutin sebelum dan selama pandemi COVID-19 di Indonesia. Penelitian ini menggunakan data sekunder yang 
bersumber dari Peraturan Menteri Kesehatan, Keputusan Menteri Kesehatan, dan petunjuk teknis pelaksanaan imunisasi selama pandemi COVID-19, kata kunci yang digunakan mencakup "Pelaksanaan Imunisasi Sebelum dan Selama Pandemi COVID-19", "Kebijakan Imunisasi Dasar di Indonesia" dan "Kebijakan Pelaksanaan Imunisasi Dasar Selama Pandemi di Indonesia". Penulis juga meneliti situs resmi Kementerian Kesehatan Indonesia dan WHO yang kemudian dianalisis untuk membandingkan pelaksanaan imunisasi rutin sebelum dan selama pandemi, setelah mengumpulkan dan membandingkan kebijakan dalam pelaksanaan imunisasi rutin di Indonesia, selanjutnya dilakukan sintesis dan analisis data.

\section{HASIL DAN PEMBAHASAN}

Berdasarkan hasil pencarian melalui internet dengan kata kunci yang telah ditentukan, penulis menemukan kebijakan yang menjadi pedoman dalam pelaksanaan imunisasi sebelum dan selama pandemi di Indonesia, pelaksanaan imunisasi sebelum pandemi diatur dalam Keputusan Menteri Kesehatan Republik Indonesia No. 1059 Tahun 2004 tentang Pedoman Penyelenggaraan Imunisasi dan Peraturan Menteri Kesehatan Nomor 12 Tahun 2017 tentang Penyelenggaraan Imunisasi, sedangkan untuk pelaksanaan imunisasi selama pandemi diatur dalam Petunjuk Teknis Pelayanan Imunisasi Pada Masa Pandemi COVID19. Diketahui bahwa terdapat beberapa perbedaan dalam pelaksanaan imunisasi rutin sebelum dan selama pandemi COVID-19, pada Keputusan Menteri Kesehatan Republik Indonesia No. 1059 Tahun 2004 menjelaskan mengenai pelaksanaan imunisasi untuk menurunkan angka kesakitan, kecacatan, dan kematian bayi akibat PD3I secara lengkap sebagai pedoman pelaksanaan imunisasi. Begitupun dalam Peraturan Menteri Kesehatan Nomor 12 Tahun 2017 tentang Penyelenggaraan Imunisasi memberikan penjelasan mulai dari jenis imunisasi, pelaksanaan pelayanan, pengelolaan limbah, hingga pemantauan dan evaluasi.

Kedua kebijakan tersebut telah menjadi pedoman dalam pelaksanaan imunisasi di Indonesia hingga akhirnya pada tahun 2020 Indonesia mengalami pandemi COVID-19, sejak saat itu terjadi penurunan cakupan imunisasi tidak terkecuali cakupan imunisasi rutin. Hal itu diakibatkan karena terhambatnya pelaksanaan imunisasi mengingat penularan virus yang sangat masif sehingga membuat orang tua takut untuk membawa anaknya ke pelayanan kesehatan (Kementrian Kesehatan Republik Indonesia, 2020), sehingga sebagai upaya meningkatkan cakupan imunisasi, Kementerian Kesehatan RI mengeluarkan Petunjuk Teknis Pelayanan Imunisasi Pada Masa Pandemi COVID19 sebagai acuan pelaksanaan imunisasi di masa pandemi. Terdapat beberapa perbedaan dalam pelaksanaan imunisasi sebelum dan selama pandemi COVID-19 diantaranya adalah sebagai berikut:

\section{Ruangan/ Tempat Pelayanan Imunisasi}

Ketentuan ruangan kini menjadi salah satu hal yang diperhatikan dalam pelaksanaan imunisasi rutin selama pandemi COVID-19, jika sebelum pandemi COVID-19 pelayanan imunisasi dapat dilakukan di dalam gedung seperti di Puskesmas, Puskesmas pembantu, rumah sakit, rumah bersalin dan polindes. Selain itu pelayanan imunisasi juga dapat diberikan di luar gedung seperti di Posyandu, kunjungan rumah, dan sekolah, serta dapat juga diselenggarakan oleh swasta seperti rumah sakit swasta, dokter praktik, dan bidan praktik, namun setelah terjadinya pandemi COVID-19, kebijakan mengenai tempat pelayanan imunisasi diperinci lagi dengan ketentuan ruangan yang harus dipenuhi sebelum memberikan pelayanan. Tempat pelayanan imunisasi harus sesuai dengan prinsip Pencegahan dan Pengendalian Infeksi (PPI) dan menjaga jarak aman 1-2 meter, tempat pelayanan harus dipastikan memiliki sirkulasi udara yang baik dan dilakukan pembersihan secara rutin dengan desinfektan baik sebelum dan sesudah pelayanan. Selain itu, tempat pelayanan perlu memiliki fasilitas mencuci tangan ataupun hand sanitizer. Pemberian jarak pada saat pelaksanaan imunisasi menjadi hal yang ditekankan di masa pandemi saat ini, seperti jarak antar meja pelayanan hingga jarak tempat duduk antar orang tua, hal diatas menjadi persyaratan tempat pelayanan imunisasi selama masa pandemi COVID-19 (Kementrian Kesehatan Republik Indonesia, 2020).

2. Waktu Pelayanan

Pada saat sebelum pandemi COVID-19 pelayanan imunisasi yang diatur dalam Peraturan Menteri Kesehatan Nomor 12 Tahun 2017 tentang Penyelenggaraan Imunisasi dilakukan serentak dengan jadwal yang sudah ditentukan. Misalnya imunisasi dasar dan lanjutan yang merupakan bagian 
dari imunisasi rutin sudah dijadwalkan sesuai dengan umur bayi dan diatur dalam interval waktu, sedangkan imunisasi lanjutan pada anak sekolah dasar dilakukan serentak di bulan yang telah dijadwalkan, berbeda dengan ketentuan waktu pelayanan imunisasi selama pandemi COVID-19 yang mengalami perincian dalam jadwal pemberian pelayanan dalam Petunjuk Teknis Pelayanan Imunisasi Pada Masa Pandemi COVID-19 dijelaskan lebih rinci mengenai waktu pelayanan imunisasi dimana sebelumnya telah ditentukan jadwal hari dan jam pelayanan khusus imunisasi di Posyandu. Pemberian pelayanan diupayakan semaksimal mungkin dengan mengatur jadwal melalui telepon antara petugas kesehatan atau kader dengan pengantar, jam pemberian pelayanan tidak perlu lama dan banyaknya sasaran dibatasi sehingga kemungkinan terdapat beberapa sesi pelayanan.

\section{Tugas dan Peran Petugas Imunisasi}

Pada Keputusan Menteri Kesehatan Republik Indonesia No. 1059 Tahun 2004, dijelaskan bahwa petugas imunisasi terdiri dari kader, petugas kesehatan Puskesmas, dan PKK yang telah memperoleh pelatihan, pada pedoman pelayanan imunisasi selama pandemi COVID19 tiap tugas para kader dan petugas kesehatan Puskesmas dijelaskan secara rinci baik sebelum maupun saat hari pelaksanaan imunisasi, hal itu bertujuan agar kebijakan yang baru dapat dipahami dengan jelas oleh para petugas dan orang tua.

4. Pelayanan Khusus

Pelayanan khusus yang dimaksud disini adalah pelayanan yang diberikan kepada anak yang masuk kriteria atau tinggal serumah dengan OTG, ODP, PDP, atau terkonfirmasi COVID-19, pada pedoman yang baru terdapat tata laksana yang harus dilakukan sebelum memberikan pelayanan imunisasi. Pada intinya bagi anak dengan kondisi khusus, pemberian imunisasi akan ditunda hingga anak sudah sehat dan terkonfirmasi negatif COVID-19 (Kementrian Kesehatan Republik Indonesia, 2020).

\section{Strategi Komunikasi}

Pada Peraturan Menteri Kesehatan Nomor 12 Tahun 2017 dijelaskan bahwa sebelum memberikan pelayanan imunisasi tenaga kesehatan wajib memberikan informasi tentang jenis vaksin, manfaat, kemungkinan terjadinya KIPI, hingga jadwal imunisasi selanjutnya. Sehingga strategi komunikasi yang dilakukan sebelum pandemi COVID-19 berfokus pada penyebaran informasi pentingnya imunisasi sesuai jadwal dan kemungkinan KIPI, sedangkan selama pandemi COVID-19, tenaga kesehatan tidak hanya berkewajiban menjelaskan hal diatas, namun diharapkan dapat meningkatkan pengetahuan, membangun kepercayaan, serta mendorong terciptanya sikap dan perilaku yang tepat terhadap informasi imunisasi rutin pada masa pandemi COVID-19 (Kementrian Kesehatan Republik Indonesia, 2020).

\section{SIMPULAN DAN SARAN}

\section{A. Simpulan}

Pelaksanaan imunisasi rutin selama pandemi COVID-19 pada intinya tidak jauh berbeda dengan imunisasi sebelum pandemi, perbedaan terdapat pada ketentuan ruangan, waktu pelayanan, tugas dan peran petugas, serta teknis pemberian pelayanan imunisasi dimana lebih diperinci dan diperketat untuk mencegah transmisi virus, adanya pedoman terbaru di masa pandemi dapat membantu para petugas kesehatan dalam menjalankan pelayanan imunisasi. Dengan adanya pedoman ini diharap orang tua tidak khawatir dan takut mengantar anaknya memperoleh imunisasi agar cakupan imunisasi yang menurun dapat meningkat kembali, upaya yang dapat dilakukan untuk tetap melaksanakan imunisasi rutin dengan aman selama pandemi COVID-19 adalah dengan menerapkan protokol kesehatan seperti memakai masker dan menjaga jarak fisik selama kegiatan, sterilisasi peralatan untuk vaksinator, menghindari ruang tunggu yang ramai, dan pentingnya praktik kebersihan yang baik untuk mengurangi resiko transmisi COVID-19 di lokasi imunisasi (Abbas et al., 2020).

\section{B. Saran}

Saran bagi para pelaksana di lapangan dan orang tua diharapkan mematuhi kebijakan yang telah ada agar pelayanan imunisasi dapat berjalan dengan lancar dan angka cakupan imunisasi dapat meningkat.

\section{DAFTAR RUJUKAN}

Abbas, K. et al. (2020) 'Routine Childhood Immunisation During the COVID-19 Pandemic in Africa: A Benefit-risk Analysis of Health Benefits Versus Excess Risk of SARS-CoV-2 Infection', The Lancet Global Health, 8(10), pp. e1264-e1272. 
doi: 10.1016/S2214-109X(20)30308-9.

Irawati, N. A. V. (2020) 'Imunisasi Dasar dalam Masa Pandemi COVID-19', Jurnal Kedokteran Unila, 4(2), pp. 205-210. Available at: http://juke.kedokteran.unila.ac.id/index. php/JK/article/view/2898/2820.

Kementrian Kesehatan Republik Indonesia (2015) Buku Ajar Imunisasi. Jakarta. Available at: http://www.pdpersi.co.id/pusdiknakes/.

Kementrian Kesehatan Republik Indonesia (2020) Imunisasi Rutin pada Anak Selama Pandemi COVID-19 di Indonesia: Persepsi Orang tua dan Pengasuh. Available at: www.unicef.org/indonesia/reports/rapi $\mathrm{d}$-assessment-immunization-servicesindonesia].

Kementrian Kesehatan Republik Indonesia (2020) Laporan Kinerja Kementerian Kesehatan Tahun 2020. Jakarta.

Kementrian Kesehatan Republik Indonesia (2020) Petunjuk Teknis Pelayanan Imunisasi pada Masa Pandemi COVID-19. Jakarta.

Kementrian Kesehatan Republik Indonesia (2021) Orang Tua Wajib Lengkapi Imunisasi Dasar Anak Meski Pandemi COVID-19.

Keputusan Menteri Kesehatan Republik Indonesia No. 1059 Tahun 2004 tentang Pedoman Penyelenggaraan Imunisasi (2004).

Mukhi, S. and Medise, B. E. (2021) 'Faktor yang Memengaruhi Penurunan Cakupan Imunisasi pada Masa Pandemi COVID-19 di Jakarta', Sari Pediatri, 22(6), pp. 336342. doi: 10.14238/sp22.6.2021.336-42.
Nadhifa, K. et al. (2020) 'Analisis Evaluasi Program Imunisasi Pada Masa Pandemi COVID-19', ResearchGate, (December).

Nurhasanah, I. (2021) 'Pelayanan Imunisasi di Masa Pandemi COVID-19: Literatur Review', Jurnal Ilmu Keperawatan dan Kebidanan, 12(1), pp. 104-108. doi: 10.26751/jikk.v12i1.899.

Pambudi, W. et al. (2021) 'Profil Capaian Imunisasi Dasar/ Lanjutan Pada Baduta Sebelum dan Selama Pandemi COVID-19', Jurnal Muara Medika dan Psikologi Klinis, 1(1), pp. 17-23. doi: 10.24912/jmmpk.v1i1.12054.

Peraturan Menteri Kesehatan Republik Indonesia No. 12 Tahun 2017 Tentang Penyelenggaraan Imunisasi (2017).

Putri, A. M., Saharuddin, S. and Fitriani, R. (2021) 'Perbandingan Pelaksanaan Imunisasi pada Masa Pandemi dan Non Pandemi Covid-19 di Puskesmas Massenga Polewali Mandar', UMI Medical Journal, 6(1), pp. 10-19. doi: 10.33096/umj.v6i1.127.

Yundri et al. (2017) 'Faktor yang Berhubungan dengan Ketidaklengkapan Status Imunisasi Anak di Puskesmas Kuala Tungkal II', Jurnal Berkala Epidemiologi, 5(3), pp. 361-370. doi: 10.20473/jbe.v5i3.2017. 